\title{
Hukuk Felsefesine Neden İhtiyacımız Var?
}

\author{
MURAT SATICI* \\ murat.satici@cbu.edu.tr \\ ORCID ID: 0000-0001-8469-3163
}

\begin{abstract}
Öz: Hukuka dair algı, ilk ve sorgulanmamış bir bakışla, sırasıyla anayasa-yasalar-mahkemesuç-ceza gibi somut hukuksal metin, uygulama ve kavramlarla sinırlıdır. Bu durum, sadece hukukun kurumsal, normatif ve adli yanını öne çıkartır ve hukukla ilgili soruları ve hukuk felsefesine neden ihtiyaç duyulduğunu açı̆̆a çıkaran felsefi kadim soruları sormayı zorlaştırırlar: Hukukun ve içerdiği adalet, hak, özgürlük kavramlarının kaynağı nedir? İkinci olarak da hukukun meşruiyetinin kaynăğ veya dayanağı nedir? Bu kadim iki sorunun hem sorulması hem de yanıtlanması, hukuk felsefesine düşer. Bu çalışmada hukukun algılanışında hakim olan yasalcı paradigmanın yol açtığı sorunların çözümünde hukuk felsefesinin önemi vurgulanacaktır. İlk olarak doğal hukuk geleneğinde hukukun ahlak ile olan kesişimine değineceğiz. Daha sonra hukuksal pozitivizmin açmazlarını vurgulayacağız. Son olarak hukuk biliminin yanında bir hukuk felsefesine neden ihtiyacımız olduğu sorusuna yanıt arayacağız.
\end{abstract}

Anahtar kelimeler: Hukuk, Yasallik, Adalet, Hukuk felsefesi, Toplum felsefesi.

\section{Giriş}

Hukuk felsefesine duyulan ihtiyacı anlamlandırmak veya gözler önüne sermek için, hukukun alışılagelmiş kurumsal-normatif yapısı veya görünümü, yani hukuk bilimi ve pratiği ile içerdiği ilke, kavram ve değerler üzerine refleksiyonları kapsayan hukuk felsefesi arasında daha sonra birleştirmek üzere ayrım yapmak gerek. Hukuka dair algı, ilk ve sorgulanmamış bir bakışla, sırasıyla anayasa-yasalar-mahkeme-suç-ceza gibi somut hukuksal metin, uygulama ve kavramlarla sinırlıdır. Bu siralamada anayasa ve yasalar devletleri oluşturan toplum sözleşmelerini, bireysel-kolektif hak ve özgürlüklerin tanımlarını, mahkeme, suç ve ceza kavramları ise hak ve özgürlüklerin çatışmasından veya ihlalinden doğan durumları ve yaptırımları işaret ederler. Bu durum, sadece hukukun kurumsal, normatif ve adli yanını öne çıkartır ve hukukla ilgili sorunların analizini ve hukuk felsefesine duyulan ihtiyacı açığa çıkaran felsefi kadim soruları sormayı zorlaştırır. Bu sorular şöyle sıralanabilir: Hukukun ve onun içerdiği adalet, hak, özgürlük ve yasa kavramlarının kaynakları nelerdir? İkinci olarak da hukukun meşruiyetinin kaynakları veya dayanakları nelerdir? Bu kadim iki sorunun

\footnotetext{
* Dr. Öğr. Üyesi, Manisa Celal Bayar Üniversitesi, Fen-Edebiyat Fakültesi, Felsefe Bölümü.
} 
hem sorulması hem de yanıtlanması hukuk felsefesine düşer.

Güncel pek çok tartışma bizi hukukun tanımı, neliği, özellikleri ve adalet ile ilişkisini düşünmeye iter. Nitekim bu tartışmalar, yasaya sorgusuz itaat etmeden önce, yasanın temel hak ve özgürlüklere göre konumunu belirlemeyi içerir. Kadın cinayetlerinde verilen hükümlerin kamu vicdanı nezdinde tartışılıyor olmasından, hayvanlara yönelik şiddet eylemlerinin hukuksal anlamda suç kategorisine dahil edilip edilmeyeceğine ve nefret söylemi ve nefret suçlarının hukuksal bağlamda ele alınış biçimindeki sorunlara kadar pek çok mesele, yasal düzenlemeler yapılıyor olsa dahi, hala üzerine tartışmanın devam ettiği ve edeceği meselelerdirler. Aslında yasal düzenlemelerle giderilmeye çalışılsa bile bu sorunlara dair tartışmayı devam ettiren unsur, adaletin yasalarda ne kadar içerildiği ve mahkeme kararlarında ne derecede somutlaştığıdır. Dolayısıyla yasalara ve mahkeme kararlarına dair akıl yürütmelerimiz ve tartışmalarımız, onların meşruiyetlerinin dayanağı olarak adaleti ne kadar içerdikleri veya somutlaştırdıklarıyla ilgilidir. Bu yüzden, hukuka ilişkin tartışmalar, sadece yasalarla ve adli kurumların işleyişiyle sınırlı değildir, aynı zamanda adalet ve hak gibi ilkelerin söz konusu hukuk sistemlerinde ne kadar içerildiğiyle ilgilidir.

İşte hukuk felsefesine duyulan ihtiyaç tam da burada açığa çıkar. Hukuku sadece normlar, hukuksal olgular ve metinler bütünü olarak görmek, hukukun içerdiği hak-adalet-özgürlük ilkeleri ve değerleri üzerine yapılacak tartışmaları engeller. Böylece hukuk, salt bir normlar sistemi olarak, konusu yasalardan ibaret kılınmış ve meşruiyetini de bu yasallıkta bulan bir edime indirgenir. Bu indirgeme, değer kategorisinde tanımlanan ve ethik ile hukuk arasındaki ilişkiyi oluşturan, bu yönüyle de felsefi olan pek çok ilkenin dışarıda bırakıldığ karşımıza çıkartır. Bunun pek çok zararından biri, öncelikle hukukun kaynaklarına ilişkin sorgulamaların engellenmesidir. Çünkü belirli bir toplumda ve belirli bir zaman diliminde geçerli olan hukuk sistemlerinin kaynakları ve meşruiyet dayanakları sistem tarafından üretilmiş yasaların mutlaklığında görülürse, o sistemlerin demokratik mi totaliter mi olduğuna dair tartışma yapma imkanı ortadan kalkar. Ayrı bir çalışmayı hak eden bu probleme kısaca değinirsek, bu tartışmayı yapmanın politik açıdan önemi şuradadır: Tikel bir hukuk sisteminin ürettiği normların dayandıkları değerlerin (hak, özgürlük, adalet) tanımlanma şekilleri ve yöntemleri, o sistemin niteliğini belirlediği kadar meşruiyetinin de kaynağını belirler. Hukuku sadece yasalar çerçevesinde ele almak, her biri hukuk sistemlerine ve yasalara sahip olan demokratik ya da totaliter sistemlerin aynı karakterde görülmesi riskini doğurur, böylece demokrasi ve totalitarizm veya despotluk arasındaki ayrım silikleşir.

Hukuk ilkelerinin kaynaklarına ve meşruiyet dayanaklarına ilişkin felsefi bir tartışmaya girişmek, çalışmamızın odağını oluşturan diğer bir meseleyi açığa çıkarır. Sorun, yukarıda değindiğimiz kadarıyla sadece hukuksal sistemlerin demokratik veya totaliter olmalarının ayrımına dair politik bir tartışmayı içermez. Hukuk felsefesi, hukukun sadece bir arada yaşamı düzenleyen zorlayıcı bir kurallar sistemi olarak betimlenmesinin ötesinde, onun herkesi bağlayıcı, yani evrensel olmasının dayanağını da sorunsallaştırır. Zira her hukuk sistemi, sadece her yurttaş için eşit derecede zorlayıcı ve cezalandırıcı olmasından dolayı değil, aynı zamanda içerdiği hak, özgürlük 
ve adalet ilkelerinin herkes tarafindan kabul edilebilir olmasından dolayı evrensellik iddiasına sahiptir. Bu açıdan bakıldığında, modern hukuk paradigmasının "hukukun üstünlüğü” ilkesinin meşruiyeti, öncelikle herkesin hukuk önünde eşitliğine dayanır. Dolayısıyla hukukun üstünlügü, tam da evrensel bir ilke olarak eşitliği tesis etmesinden doğar. O halde hukuk, sadece yasaların kendilerine bağlanmış bir evrensellik iddiasına dayanmaz. Hukuka evrenselliğini veren, eşitlik, hak, özgürlük ve adalet ilkelerinin yasalarda cisimleşmesidir. Bu ilkeler, yasaların dayandıkları ve yasalarda cisimleșen ilkeler ve değerlerdir. Bu haliyle Antik Yunan'dan on dokuzuncu yüzyıla kadar olan süreçte karşımıza çıkan doğal hukuk geleneği, yasalar ve onların dayanakları olan evrensel ilkeler arasındaki ilişkiyi merkeze alan bir hukuk felsefesi geleneğini oluşturmuştur. Aslında tam anlamıyla yasaların içerecekleri ilkelerin, yani hak, özgürlük ve adaletin nasıl tanımlanacağı tartışmasını yaptığı oranda, doğal hukuk geleneğini ahlakın da içerildiği felsefi bir edim olarak karşılamak mümkündür. Zira "doğal hukuk, hukuk ile ahlak arasındaki kesişim noktasına isim verir. Basitleştirirsek, ana iddiası şudur: Doğal olan ne ise o, olması gerekendir".

\section{Ahlak ve Hukuk: Doğal Hukuk ve Hukuk Felsefesi}

Doğal hukuk kavramsallaştırması, hukukun evrenselliğini ve tikel yasaların meşruiyetini sağlayacak olan ilkelerin yüksek konumunu işaret eder. Bu konum, felsefe tarihi içerisinden çıkarsanır. Nitekim Antik Yunan'da doğanın bir düzenlilik modeli olduğu felsefi paradigmada, site, yani kent devleti, insanın insanlaşabileceği bir doğayı, makrokozmosun yanında bir mikrokozmosu işaret eder. Bu nedenle site ve birey arasında kurulan varoluşsal ilişki yasayı ve doğayı birbirlerine eklemlemiştir. Yasa bu anlamda insansal doğayı işaret ettiği gibi, yasayı düşünmek hem siteyi hem ahlakı hem de politikayı birlikte düşünmektir. Bu nedenle Sokrates'in idam cezası ile karşı karşıyayken siteden sürgün edilmeyi veya kaçmayı kabul etmemesi anlamlıdır. Sokrates için siteden uzaklaşmak yasadan, yurttaş olmaktan, dahası insan olmaktan uzaklaşmak demektir. Bu nedenle Antik Yunan'da hukuk, insan yaşamını, siteyi ve hem insanlar hem de site için iyi yaşamı, iyinin ölçütünü ve adaleti sorgulamaktır. Platon, kendileri de yasalara uymak zorunda olan ve onların hizmetçileri olan yöneticilerin bilgelikleri aracılığıla tesis edilen politik düzenin ahlaksal bakımdan iyi ve adil olacağını belirtir. ${ }^{2} \mathrm{Bu}$, hukuku sorgulamanın, hem ahlaksal hem hukuksal hem de politik felsefi bir sorgulamayı içerdiği anlamına gelmekteydi. Elbette ki ahlak ve politika kesişimindeki hukuk düşüncesinde içerilen yüksek değerlerin bilgisinin somut, tikel durumlara uygulanabilmesi de gereklidir. Platon, filozofun ahlaksal normlara dair bilgeliğini, onun yönetici olarak adil bir toplum yaratma iradesiyle birleştirerek, hukuk felsefesinin, evrensel ilkelerin bilgisine sahip olan akıl ve yasa yapma iradesi arasındaki ilişki sorunsalını politik bağlamda çözmeye yönelir. Daha sonra Aristoteles, yasa koyucuların, bilgisine sahip oldukları ezeli ebedi ilk ilkeleri tikel durumlara uygulamaları gerektiğini, yani evrensel ilkelerin tikel yasalarda cisimleşmesi gerektiğini vurgular. Aristoteles, yasa koymayı, neyin adil ya da adil olmadığına dair pratik bir yargı edimi olarak tanımlar. İnsanın zoon politikon olarak 
tanımından hareketle Aristoteles, yasa koymayı her yurttaşta ortaklaşa bulunan bir özellik biçiminde tanımlar. Böylece yasa yapma, ortak iyiyi bulma ve ona katılma olarak ahlaksal iyinin hukukla ilişkisini yeniden sağlayacak biçimde tanımlanmıştır. Böylece Aristoteles’te "erdemi emreden, erdemsizliği yasaklayan bir şey"3 olarak yasa, doğru, iyi ve adil olanla aynı anlama gelir. Bu sorgulamanın dilsel bir edim gerektirdiği kaçınılmaz olarak söylenmelidir. Aslında Aristoteles’te akıl ve dil, yasada birleşir ve cisimleşir. Bu da Antik Yunan Felsefesi’nde yasanın, hukuksal olduğu kadar uzlaşımsal, politik ve felsefi olan karakterini açığa çıkarmıştır.

Stoacılarla birlikte ise Evrensel Akıl'a uygun olmayan yasaların geçersiz olacağı anlayışı ekseninde bir evrensellik modeli ortaya çıkar. Stoacılık, insanın biyolojik varoluşunu yine insan türünün toplumsal varlığı ile tanımlayarak antropos'u, tüm insansal varoluşu içeren evrensel bir kavrama dönüştürmüştür. Dolayısıyla evrensel aklın yasası, onunla eşit biçimde ontolojik olarak bağlı olan tüm insanlar için evrenseldir. Cicero’ya göre, "pek çok yasada içsel olan, adil olanı ve doğruyu seçme duyusu ve düşüncesidir. Böylece, bir toplulukta herhangi bir türden bir yasa, insanlar kabul etmiş olsalar bile, doğru aklın ebedi adaletine uymadıkça bir yasa olmayacaktır”." Daha sonraları Stoacı ortak akla sahip insanlık idesi, artık geniş ve kozmopolit bir imparatorluk hukuku çerçevesinde ihtiyaç duyulan yurttaşlık bağını tesis etmekte temel teşkil etmiştir. Roma, imparatorluğun organik olarak birbirine bağlanmış eşit haklara sahip yurttaşlar topluluğu olarak tanınmasında, hukuku bu birliğin ifadesi olan akılsallık olarak benimsemiştir.

Ortaçağ’da ise yasalara ilişkin evrensellik ölçütü Augustinus ile birlikte kaynağını Tanrida bulmuştur. Adalet olmadan devletlerin büyümüş haydut çetelerinden başka bir şey olmadığını söylerken Augustinus, adaletin kaynağını Tanrı Devleti’nde, yani yeryüzündeki devletlerin ve hukuk normlarının üzerindeki aşkın bir dayanakta aramıştır. ${ }^{5}$ Yine Thomas Aquinas'ın Ebedi hukuk (Tanrıya özgü), Doğal hukuk (akıl tarafından keşfedilebilen), İlahi hukuk (kutsal metinlerde açığa çıkan) ve İnsan hukuku (aklın desteklediği ve genel iyiye yönelik) ayrımı, Ortaçağ’ın hukuk anlayışının temel karakterini yansitır. Thomas'a göre, doğal veya ilahi olmayan hukuka uygun olmayan bir hukuk, hukuk değildir. "Başka bir deyişle, adil olmayan (akılcı olmayan veya genel iyiye karşı olan) kanunlar düzenleyerek otoritesini kötüye kullanan bir yönetim, itaat edilme hakkını yitirir çünkü ahlaki otoriteden yoksundur. Böyle bir kanuna Aquinas 'hukukun yozlaşması' der. ${ }^{6}$

Rönesans’in evreni açıklama modelinde Kopernik ve Galileo tarafından gerçekleştirilen devrimin Machiavelli ile birlikte politik alanda, politikanın ve sivil toplumun otonomisi lehine gerçekleşmesi, modern hukukun evrensellik ilkesi açısından başvuru temelini değiştirmiştir. Genel olarak rönesansta "her şeyden önce yukarıdan gelen ışık, Rönesans resminde yerini bu dünyadan, konuya yatay olarak gelen ışığa bırak-

3 Aristoteles, Nikhomakhos'a Etik, çev., Saffet Babür, Ankara: Kebikeç Yay., 2005, 1130 b 25.

4 Akt., David Ingram, Law, London: Continuum İnternational Publishing Group, 2006, s.16.

5 Mehmet Ali Ağaoğulları ve Levent Köker, İmparatorluktan Tanrı Devlete, Ankara: İmge, 2004, s.154.

6 Wacks, Hukuk Felsefesine Kısa Bir Giriş, s.4. 
mıştır”. Nitekim Machiavelli tarafından, egemenliğin, iktidarın kaynağını Tanrı'da temellendirme zorunluluğu olmadığının ilan edilmesinden sonra, Hobbes ve Locke ile başlayan sözleşmeci hukuk teorilerinin evrensellik ve meşruiyet dayanağını doğal özgürlügün düzenlenmesini düzen ve güvenliğimizde gören modern hukukun çehresi değişmiştir. Hobbes, doğal durumdaki 'herkesin herkesle savaşı'ndan ${ }^{8}$ çıkmasını sağlayan sözleşmeyle sadece düzeni ve güvenliği değil, akılsal her insanın kendi varlığını korumaktan başka ölçüt kabul etmediği durumu, ahlaksal iyi-kötü ve politik hak ve adaletin akılsal olarak temellendirildiği bir politika ve hukuk kavramsallaştırmasını kurmuştur. Locke’a göre ise yaşam, özgürlük ve mülkiyet doğal haklar olarak tanımlamıştır ${ }^{9}$ ve toplum sözleşmesi genel iyiyi sivil toplumda cisimleştirmiştir. Yani Locke, doğal haklarımızı doğa yasalarıyla sınırlandırmıştır ve yaşam, özgürlük ve mülkiyete doğal durumda zarar vermememiz gereklidir. Fakat radikal durumlarda ortaya çıkan hak çatışmalarını önleyecek olan yasama gücü ve yönetim kuvvetleri tarafından uygulanacak denge ve kontrol mekanizmaları özgürlüğü artıracak, devleti ise küçültecektir. O halde Locke için doğa yasası, ebedi ve ezeli bir yasa olarak hem insanların yaşam, özgürlük ve mülkiyetlerini korumakta onları sınırlayacak, hem de yasa koyucuları bağlayıcı bir niteliğe sahip olacaktır. Böylece hak, özgürlük ve adaletin tesisi ve güvenliği için gerekli yasalar, meşruiyetlerini insanları ve yasa koyucuları bağlayacak bir doğa yasasından türetecektir.

Rousseau'nun temel itirazını oluşturan, mülkiyetin doğal hak ve doğa yasası olarak tanımlanması ve onu insanlar arasındaki eşitsizliğin kaynağı olarak görmesidir. Doğal ve politik eşitsizlik ayrımında Rousseau’ya göre politik eşitsizlik, "kimilerinin başkaları zararına yararlandığı, örneğin onlardan daha zengin, daha itibarlı olmak ya da onlara boyun eğdirmiş olmak gibi ayrıcalıklardan ibarettir”. ${ }^{10}$ Rousseau mülkiyeti bir uygarlık ilkesi olarak değil, insanların kendilerine ve birbirlerine yabancılaşma yaratan bir ilke olarak görmüştür. Buradan hareketle toplum sözleşmesi bu insanlık durumunun yarattığı en büyük eksikliği, yani eşitsizliği giderebilmek için genel iradenin tesisini hak ve adalet anlayışının merkezine koymaktadır. Toplum sözleşmesi bu yanıla birey ve toplum arasında bir sözleşmeyi işaret ederken birey bu yolla genel iradenin parçası haline gelir. Dolayısıyla hak, bir yurttaşlık bağından hareketle inşa edilir ve her türlü eşitsizliği dışarıda bırakan bir hukuk, her yurttaşın genel iradeye katılımını sağladığı oranda birliği tesis edebilir. "Her birimiz bütün varlığımızı ve bütün gücümüzü bir arada genel istemin buyruğuna verir ve her üyeyi bütünün bölünmez bir parçası kabul ederiz"11.

On yedinci yüzyıla gelindiğinde modern ve aydınlanmacı akıl kavrayışıyla evrensellik iddiası seküler biçimde insansal doğanın bir arada yaşama önündeki doğal engellerine karşı evrenselleştirici unsur olarak hak ve adaleti rasyonel bir yöntemle

7 Tülin Bumin, Tartışılan Modernlik: Descartes ve Spinoza, İstanbul: YKY., 1996, s.10.

8 Thomas Hobbes, Leviathan, London: The Green Dragon, 1651, XIV.

9 John Locke, Two Treatises of Government, ed. Peter Laslett, Cambridge: Cambridge University Press, 1988, s.269.

10 Jean-Jacques Rousseau, İnsanlar Arasındaki Eşitsizliğin Kaynakları, çev., Rasih Nuri İleri, İstanbul: Say Yay., 1998 , s.87.

11 Jean-Jacques Rousseau, Toplum Sözleşmesi, çev., Vedat Günyol, İstanbul: Türkiye İş Bankası Kültür Yayınları, 2006, s. 15. 
aramıştır. Kant’ın söylemiyle hak tanımı, aynı zamanda köklerini rasyonel ahlakta bulan bir arada yaşamı işaret etmekteydi:

Herhangi bir eylem, evrensel bir yasaya uygun olarak herkesin özgürlügüule bir arada varolabiliyorsa ve bu eylemin maksiminde herkesin seçme özgürlüğü evrensel bir yasaya uygun olarak herkesin özgürlüğüyle bir arada var olabiliyorsa haklıdır. ${ }^{12}$

Hukuk felsefesi tartışmalarında diğer filozoflar (Hobbes, Locke, Rousseau) kadar adı geçmese de Kant'ın bilim ve ahlakta veya teorik ve pratik alanda evrensel bilgi ve evrensel ahlak ilkeleri tesis etme çabasında ortaya çıkan evrenselleşebilirlik vurgusunun hukuk felsefesine katkısı önemlidir. Kant, tüm sistemiyle uyumlu biçimde, teorik ve pratik alanda özneler arası bir denetlemeyi bilimsel bilgi ve ahlaksal iyinin merkezine evrensellik ilkesi olarak koymuştu. Evrensel hak tanımında ise Kant, eleştirel sistemiyle tutarlı biçimde, kişinin seçtiği eylemin haklılı̆̆ının koşulunu, eylem maksiminin diğer kişilerin seçme özgürlükleriyle bir arada varolma zorunluluğunda görmüştü. Bu zorunluluğun denetimi için Kant'in başvurduğu yöntem ise kişilerin hem kendi hem de başkalarının eylem maksimlerini eleştirmesidir. Onun felsefesinin eleştirel felsefe olarak anılmasının nedeni, kendinden önceki düşüncelere eleştiri getirmesinin yanında teorik ve pratik problemlerde, hukuk ve politika da dahil olmak üzere, özneler arası bir dolayımın ve eleştirinin imkanını merkeze almasıdır. Bu yanıyla Kant’ın evrensellik ölçütü, ahlaksal eylemlerde buyruk olarak tesis ettiği "insanlığ1 araç olarak değil amaç olarak görme" ve "herkes için geçerli olma"13 yasalarıyla açığa çıkar ve bunlar, daha sonra Evrensel İnsan Hakları düşüncesinin ahlaksal ve felsefi temelini oluştururlar. Dolayısıyla Kant'in felsefesinde içerilen evrensellik ilkesi ve insanlık idesi, genel ve tikel tüm çağdaş hukuk metinlerinin dayandığ Evrensel İnsan Hakları kavramsallaştırmasının ve bundan türeyen tüm bağlayıcı formel metin, anlaşma ve sözleşmelerin felsefi kaynağıdır.

\section{Hukuk Bilimi Varken Neden Hukuk Felsefesi?}

Kant'in felsefesindeki evrensel ahlak ve hukuk kavramsallaştırmasının ondan sonraki ele alınışı modern hukukun çehresini belirlemiştir. Kant’ın formel bir evrensellik ilkesine yaptığı vurgu daha sonra özellikle hukuka üstünlük niteliğini atfetmemize neden olan prosedürel yapısının da temellerini oluşturur. Hans Kelsen, Jeremy Bentham, John Austin ve H.L.A. Hart gibi hukuk teorisyenleri, hukukun prosedürel karakterini öne çıkararak pozitivizmin doğa bilimlerindeki egemenliğini pratik alanlara uygulama çabasının da ürünü olan bir hukuk bilimi tanımına ulaşırlar. Bu çaba, hukukun saf, içeriksiz ve otonom bir bilim olarak tanımlama amacına hizmet eden hukuksal pozitivizm aracılığıyla doğal hukukun felsefi akıl yürütme biçimini terk ederek bir bilim olarak hukuku tanımlamayı getirdi. Hans Kelsen, Saf Hukuk Teorisi adlı eserinde, teorisini, "sadece yasayı tanımladığı ve kesin biçimde yasa olmayan her şeyi bu tanımlamanın nesnesi olmaktan çıkarmaya çalıştığı için yasaya ilişkin saf bir

12 Immanuel Kant, The Metaphysics of Morals, trans., Mary Gregor, New York: Cambridge University Press, s.230.

13 Immanuel Kant, Groundwork of the Metaphysics of Morals, trans., Mary Gregor, New York: Cambridge University Press, 1997, 4:429. 
teori olarak adlandırdığını ve teorisinin amacının, hukuk bilimini yabancı öğelerden özgür kılmak olduğunu" ${ }^{14}$ belirtir. H.L.A. Hart ise, ahlaki biçimde adaletsiz olarak düşünülse dahi usulüne uygun çıkarılmış olan ve anlaşılır olmasının yanında belirli bir düzenin kabul edilmiş geçerlilik ölçütlerine uygun olan yasaları değerlendirmeyi esas almış ve bu yasaların hukuksal veya geçerli olup olmadıklarıyla ilgilenmeyi tercih etmiştir. Hart, herhangi bir yasanın ahlaki anlamda kabul edilemez olmasının o yasanın hukuk niteliğini kazanmasına engel teşkil etmeyeceğine ulaşır. ${ }^{15} \mathrm{Bu}$, hukuku ahlaksal, felsefi temellerinden ayıracak ve böylece bilimin olduğu gibi hukuk da kendi konuları üzerinde genel geçer normlara ulaşabilecekti. Hukuksal pozitivizm ile birlikte, hukukun olgularının sadece yasalar olduğunun kabulü ve yasalar dışında başka hiçbir şeyin hukukun ilgi alanına girmediği anlayışı hukuk teorisi ve pratiğinin merkezine yerleşti. Bunun sonunda hukuk, teorik zeminde hem bir bilim olarak otonom bir evrensellik ölçütü kazanacaktı, hem de bu ölçüte uygun, yani ahlaksal, sosyal içeriklerden bağımsız prosedürel yasalara dayanarak uygulanan hukuk pratiği hukukun bağımsızlığını ve üstünlügünü tesis edecekti. Hukukun üstünlüğü sorunsalının çözümü, adeta ahlaksal, sosyal ve felsefi her türlü sorgulamanın hukukun dışına atılmasıyla mümkün görüldü. Bu yolla hukukun otonomisi, hukuku yasalara indirgeyerek, hukukun çağımızdaki formel ve prosedürel yöntemle uygulanmasının önünü açan bir biçimde tanımlanmış oldu.

Bu durum, yazımızın başında işaret ettiğimiz iki soruya yine de cevaplar verir, fakat bazı problemleri de içerisinde barındırır. Hatırlayacak olursak sorularımız aşağıdaki gibidir: Hukukun ve içerdiği adalet, hak, özgürlük kavramlarının kaynağı nedir? İkinci olarak da hukukun meşruiyetinin kaynağı veya dayanağı nedir? Hukukun yasalar ve prosedürlere indirgenmesi, adalet, hak ve özgürlük kavramlarının kaynağını belirli bir zaman, koşul ve kişiler tarafından yapılan anayasalara ve yasalara bağlar. $\mathrm{Bu}$ andan itibaren yukarıdaki ilke ve kavramların kaynağı, yasaları yapanların iradeleridir veya emirler manzumesidir artık. "Kurucu anayasanın belirlenimine bağlı yasal düzendeki öznelere kalan tek eylem, onaylanan ilk yapıyı koyan bir birey veya bireyler gibi davranma zorunluluğudur" ${ }^{16}$ Burada hukuk felsefesi açısından sorun, hukukun kaynağının ve meşruiyetinin dayanağının artık yasaya uygunlukta bulunmasıdır. Yasaya uygunluk, burada hukukun meşruiyetinin kaynağı olmakla beraber, yasaların geçerliliği ise kural koyucunun iradesinde bulunur. Dolayısıyla haksız veya adaletsiz olana dair karar verici ölçüt yasanın kendisidir. Fakat hukuk, yasanın haksızlığını veya adaletsizliğini denetleyebilecek tartışmalara, yasa hukukun yegane öğesi kılındığı için, girmez. Çünkü hukuksal alan ethik sorunlardan bağımsız bir karaktere sahip olarak tanımlanmıştır.

Oysa hukuk, haklar ve adalet üzerine düşünülmeden tanımlanamaz. Hak ve adalet düşüncesi hukuk sistemlerine nüfus etmiştir ve hukuk felsefesi bu nedenle hukuk sistemleri için merkezi bir önem taşır. Zira adaletin tecellisi, hukuk sistemlerinin merkezi amacıdır ve adalet bu yüzden ister pozitivist ister normatif olsun hukuk sis-

14 Hans Kelsen, Pure Theory of Law, trans., Max Knight, California: University of California Press, 1967, s.1. 15 Herbert Lionel Adolphus Hart, Hukuk, Özgürlük ve Ahlak, çev., Erol Öz, Ankara: Dost Kitabevi, 2000, s.79. 16 Hans Kelsen, General Theory of Law and State, trans., Andres Wedberg, New York: Russel and Russel, 1973, s.115 ve Kelsen, Pure Theory of Law, s.199-200. 
temlerinin dayandığı ve bu sistemler aracılığıyla gerçekleşebilecek bir erdem olarak hukukun varlığının koşuludur. Fakat bir yandan da adalet, tam da hukuk sistemlerinin evrenselliğinin koşuludur. Çünkü adaletin kendisi, hukukun pozitif yorumunu aşan ve hukukun evrensellik talebini karşılayan yegane ilkedir. Nitekim her ne kadar adalete ilişkin ethik ve felsefi tartışmalardan soyutlanmaya çalışılsa veya pek çok ülkede farklılıklar gösterse de hukukun ve hukuksal uygulamaların hem dayanacağ ilke hem de karşılayacağı eksiklik ve ihtiyaç adalettir.

Benzer durum hak ilkesi için de geçerlidir. Zira hukukun sadece prosedürlere indirgenmiş karakteri, haklar konusundaki tartışma alanını daraltıcı bir niteliğe sahiptir. Temel bireysel ve kolektif hakların anayasa ve yasalarca tanımlandığı aşikardır. Fakat yasaların haklar ile ilişkilerini değerlendiriken statik bir yoruma bağlı kalmanın getirdiği sorunlar da bir o kadar önemlidir. Yasalarca tanımlanan hakların zaman içerisinde bireysel ve kolektif yeni hak taleplerini veya mevcut kapsamlarının genişletilmesi taleplerini karşılaması da gereklidir. Belirlenmiş normların içerdiği hak ve özgürlük taleplerinin zamanla yeni tanım ve talepleri karşılayacak biçimde dinamik bir yapıya sahip olmaları gerekir. Belirli bir zamanda hakları tanımlayan yasaların artık bu tanımları aşan yeni hak tanımlarını içerecek biçimde değiştiği ve dönüştüğü siyasi tarihin köklü dönüşüm ve devrimlerinde görülmüştür. Zamanla ortaya çıkacak yeni hak ve özgürlük taleplerinin ortaya çıkması kaçınılmazdır. Hukuk sistemlerinin demokratik olup olmadıklarının ölçütü de zaten yeni talepleri mevcut yasalarca içerilen hak tanımlarına uydurmak, uymayanları dışarıda bırakmak değil, bu talepleri karşılayabilecek dinamiğe sahip olmasıdır. Zira yasalar, geçmiş hukuksal eylemlerce görünür olan hakların cisimleşmesi olmalarına rağmen, yasaların meşruiyet ölçütü olarak adalet, insanların özgür, politik, bireysel veya kolektif deneyim, eğilim, ilgi ve taleplerine bağlıdır. Bu yüzden bu taleplerin ortaya çıkabilmesi, yorumlanması, değerlendirilmesi ve hukuk sistemlerince kabul edilmesi yeni hak ve özgürlük taleplerini içerecek yasaların yapılması her şeyden önce eleştirel, moral, politik niteliğe sahip bir demokratik düşünümü gerektirmektedir. Bu edim beraberinde hak-adalet-özgürlük-eşitlik kavramlarının moral, politik ve hukuksal açıdan yeni yorumlarının, tanımlarının yapılmalarını, yani aslında hukuk üzerine çağdaş bir felsefi düşünümü gerektirmektedir.

Yurttaşların, hukuksal kurumların ve organların yasalara dair demokratik konumları, aslında onların içerdikleri hak, özgürlük, adalet gibi ilkelerin yeni koşullarda yeniden ele alınması ihtiyacını karşılayan bir akıl yürütmede ortaya çıkar, onlara sorgusuz itaatte değil. Zira modern demokratik toplumlarda hukukun üstünlügüne bağlılık, hukukun yurttaşları eşitler olarak gören karakterinde tek tek her bir yurttaşı politik bir birliğin üyeleri olarak betimlemesinden kaynaklanır. Bu, hukukun ve hukuk üzerine düşünüm olarak hukuk felsefesinin, artık daha önce bahsettiğimiz doğal hukuk öğretilerinde içerildiği biçimiyle haklara, adalete ve özgürlüklere ilişkin felsefi düşünümün temeline ve meşruiyet sorunsalının çözümüne aşkın ilkeleri veya pozitivist görüşte olduğu gibi salt prosedürel bir indirgemeyi koyamayacağı anlamina gelir. Bu, hem hukukun hem de yasaların meşruiyetinin dayanağı sorununun çözümüne, hukuk felsefesi aracılığıyla, artık toplumun kendi eliyle yarattığı kurumların 
işleyişine dair eleştiriyi, yorumlamayı, moral ve politik bir yargılama yetisini koymak demektir. Aslında bu, "kanunun muhalif süreçlerle ve vatandaşlarca deneyimlenerek geliştirilmesi ve test edilmesi”"17 anlamında hukuksal ve politik eylemlerin dönüştürücü etkisini işaret eder. Doğal hukuk geleneğinde hakim olan hukukun meşruiyeti sorunsalına cevaben içerilen evrensel ve zaman üstü hukuk kavramının yerini çağdaş hak ve hukuk felsefesinde hukuksal sistemlerin yanlış yönlerine yönelen, aşkın ilkeleri veya değerleri değil, sisteme içkin değerleri ele alan çağdaş felsefi bir sorgulamanın alması gereklidir.

Böylesi bir çağdaş hukuk felsefesinin genel hatlarıla hem doğal hukuk geleneğini hem de pozitivist bakış açısını aştığını söyleyebiliriz. Bu yanıyla sorun artık hukukun meşruiyeti ve hak, özgürlük ve adalet ilkelerine ilişkin zamanüstü tanımlama çabasını aşar. Nitekim özellikle bizi, yasanın ve yargı kararlarının haklı veya adil olup olmadığını sorgulamaya yönelterek hukuk biliminin ve hukuka dair yaygın görüşün sınırlarını aşmaya zorlayan şey, çağımızın insansal sorunlarının bizi yönelttiği pratik felsefenin sorunlarıdır. Çünkü çağımız konjoktürünün de etkisiyle biliyoruz ki artık "hukuk ne Tanrı tarafından bildirilmiştir ne de bilim tarafından keşfedilmiştir; onun taşıdığı değerleri dikkate almaksızın yorumlayarak incelemeyi meslek haline getirenlerin de katılımıyla oluşan tamamen insan yapımı bir eserdir". ${ }^{18}$ Hukukun insan yapımı olması vurgusundaki hayati nokta, hukukun ve yasaların yapımında ve yapılış yönteminde içerilen katılım ve çoğulculuk tartışmalarıdır. Bu yanıyla hukuk, hukuk felsefesinin yardımıyla, bireysel ve kolektif haklar, politik katılım ve anayasa yapım süreçlerinde kamusallığı ve katılımı kısıtlayıcı her türlü otoriter iktidar pratiklerini sorunsallaştırmadan düşünülemez. Özellikle kamusallık ve kamusal alan kavramları, Habermas'in vurguladığı biçimiyle hukuk teorisinin içerisinde değerlendirilebilir ve katılımcıların bakış açılarını, politik yasa yapıcı yöneticileri veya özel yasal kişi ve yurttaşların rollerini kapsamalıdır. Zira Habermas'a göre, yasaların meşruiyeti sorunları gibi hukuksal sorunlar, ahlaksal ve politik sorunlardır ve müzakereci bir demokrasi ve kamusallık kavramları temelinde politik felsefe içerisinde ele alınmalıdır. Ona göre hukukun etkin biçimde işleyen bir kamusal alan içerisinde kurumsallaşabilir olduğu durumda bireysel yargılamanın pratik, hukuksal ve politik bir yargılama meselesi olarak görülmesi mümkün olur. Genel bir tanımlamayla Kamusallık,

adalete ilişkin normatif meseleler ile iyi yaşama ilişkin değer meseleleri arasındaki ayrımdır (...) Bu ayrım, ne temel doğal bir hakka dayanır ne de öncelikli iyilerin teminat altına alınmasına referansla gerçekleşir. Bundan ziyade, ihtiyaçlara ilişkin iletişimsel yorum ve söylemsel tartışma süreci içerisinde tüm ilgili olanlarca geçerliliği tanınan o ilgi ve ihtiyaçların tatmini, iyi yaşama ilişkin tikel kavrayışların peşinden koşmanın üzerindedir. Aynı zamanda pratik söylemde etkili bir katılım için gerekli olan genel toplumsal koşullar, tüm bireylerin sahip oldukları meşruiyet iddiasına ilişkin adalet ve hak meselesi olarak görülür. ${ }^{19}$

17 Ronald Dworkin, Hakları Ciddiye Almak, çev., Ahmet Ulvi Türkbağ, Ankara: Dost Kitabevi, 2007, s.258-259. 18 Alain Spuiot, Homo Juridicus, çev., Bilge Açımuz Ünal, Ankara: Dost Kitabevi, 2005, s.21.

19 Kenneth Baynes, The Normative Grounds of Social Criticism, New York: State University of New York, 1992, s.7. 
Hukuksal ve yasal meşruiyetin kaynağı tam da bu kamusallık tanımının içerdiği müzakerede ve onun sonucunda cisimleşir. Nitekim Habermas, normatif bir demokrasi teorisini, yani müzakereci demokrasiyi tam da yurttaşların oluşturduğu ve müzakereye dayalı kanaat ve iradeyi tesis edecek olan iletişim koşullarının cisimleşmesi olarak görür. Dolayısıyla onun için demokratik bir haklar ve hukuk sisteminin meşruiyetinin kaynağı da bu müzakereci demokrasi modelidir. Zira "meşruluğun kaynağı, bireylerin önceden belirlenmiş iradesi değildir, (...) bizzat müzakere edilme sürecidir".20

\section{Sonuç}

Kuşkusuz Habermas'ın görüşlerinde açığa çıktı̆̆g şekliyle, fakat radikal demokrasi, Feminist hukuk kuramları, insan hakları tartışmaları, lokal ve global ölçekte yaşanan hak ihlalleri ve savaşların gözler önüne serdiği biçimde, hukuk üzerine düşünüm, hak, adalet, yasa gibi ilkelerin içerildiği fakat hukukun sınırlarını aşan biçimde politik alanı da işgal eden çağımız sorunlarını kapsamaktadır. Nitekim, çağdaş hukuk kuramlarının ortaklaştığı nokta, artık hukuku yasalara indirgemeyi aşan biçimde, çok kültürlü, çoğulcu, çok kimlikli bir dünyada dile getirilen özgürlük, eşitlik ve adalet ihtiyaçlarına nasıl cevap verilebileceğidir. Hukukun veya yasanın meşruiyetine ilişkin kadim soru, herhangi bir hegemonik grubun altında baskılanmadan ve yok olmadan birbirinden farklı tikellikler ve grupların haklarını tanıyacak politik ve hukuksal birarada yaşam normlarını nasıl tesis edeceğimiz sorusuna evrilmiştir. $\mathrm{Bu}$ soru, politik olarak da, çoğulculuğun nasıl maksimize edilebileceği ve lokal ve global ölçeklerde yurttaşlar olarak farklılıklarımızı ve onlardan doğan adalet ve hak taleplerimizi nasıl tanımlayabileceğimiz ve yaşayabileceğimiz sorusuna genişlemiştir.

Çağdaş hayati sorunların bizleri getirdiği noktada hukuka ilişkin tartışmalar elbette salt yasallık indirgemeciliğinde hukuka yaklaşmamızı engeller. Zira insan hakları, hayvan hakları, ekoloji ve doğa problemleri, dijital ve siber teknolojiler aracilığıyla genişleyen hak ve özgürlük problemleri, nefret suçları vb. sayılamayacak pek çok yaşamsal sorunun karşımıza çıkardığı yeni hak, adalet, özgürlük ve suç tanımları bizi hukuk teorisini ve pratiğini yeniden düşünmeye yöneltir. Tam da bu nokta, başta sorduğumuz, yani hukuk felsefesine neden ihtiyacımız olduğu sorusu üzerine düşünmenin bir başlangıç noktası olacağını göstermekte. Zira tüm çağdaş meselelerin açtığı tartışma alanları ve doğurduğu yeni sorular, insansal alanın kendisi üzerine düşünmeyi gerektirmesi açısından her alandaki felsefi sorgulamaları gerekli kılmakta. Hukuk felsefesine neden ihtiyacımız olduğuna dair sorumuz, tüm yaşamsal alanlardaki problemlerin tanımını, eleştirisini ve yeni yönelimlerini belirlemeyi mümkün kılacak bir sorgulamanın kendisine duyduğumuz ihtiyaçtan bağımsız değildir.

20 Jürgen Habermas, Kamusallĭgın Yapısal Dönüşümü, çev., Tanıl Bora ve Mithat Sancar, İstanbul: İletişim Yay., 1997, s.43. 


\section{Kaynakça}

Ağaoğulları, Mehmet Ali ve Levent Köker. İmparatorluktan Tanrı Devlete. Ankara: İmge Yayınevi, 2004.

Aristoteles. Nikhomakhos'a Etik. Çev., Saffet Babür. Ankara: Kebikeç Yay., 2005.

Baynes, Kenneth. The Normative Grounds of Social Criticism. New York: State University of New York, 1992.

Bumin, Tülin. Tartışılan Modernlik: Descartes ve Spinoza. İstanbul: YKY., 1996.

Dworkin, Ronald. Hakları Ciddiye Almak. Çev., Ahmet Ulvi Türkbağ. Ankara: Dost Kitabevi, 2007.

Habermas, Jürgen. Kamusallı̆̆ın Yapısal Dönüşümü. Çev., Tanıl Bora ve Mithat Sancar. İstanbul: İletişim Yay., 1997.

Hart, H.L.A. Hukuk, Özgürlük ve Ahlak. Çev., Erol Öz. Ankara: Dost Kitabevi, 2000. Hobbes, Thomas. Leviathan. London: Green Dragon, 1651.

Ingram, David. Law. London: Continuum International Publishing Group, 2006.

Kant, Immanuel. Groundwork of the Metaphysics of Morals. Trans., Mary Gregor. New York: Cambridge University Press, 1997.

Kant, Immanuel. The Metaphysics of Morals. Trans., Mary Gregor. New York: Cambridge University Press, 1991.

Kelsen, Hans. General Theory of Law and State. Trans., Andres Wedberg. New York: Russel and Russel, 1973.

Kelsen, Hans. Pure Theory of Law. Trans., Max Knight. California: University of California Press, 1967.

Locke, John. Two Treatises of Government. Ed. Peter Laslett. Cambridge: Cambridge University Press, 1988.

Platon. Yasalar. Çev., Candan Şentuna-Saffet Babür. İstanbul: Kabalcı Yay., 1998.

Rousseau, Jean-Jacques. İnsanlar Arasındaki Eşitsizliğin Kaynakları. Çev. Rasih Nuri İleri. İstanbul: Say Yay., 1998.

Rousseau, Jean-Jacques. Toplum Sözleşmesi. Çev. Vedat Günyol. İstanbul: Türkiye İş Bankası Kültür Yayınları, 2006.

Spuiot, Alain. Homo Juridicus. Çev., Bilge Açımuz Ünal. Ankara: Dost Kitabevi, 2005.

Wacks, Raymond. Hukuk Felsefesine Kısa Bir Giriş. Çev., Engin Arıkan. İstanbul: Tekin Yayınevi, 2014. 
İNSAN\&İNSAN, Y11/Year 6, Sayı/Issue 21, Yaz/Summer 2019, 713-724

DOI: https://doi.org/10.29224/insanveinsan.518261

\title{
Why We Need the Philosophy Of Law?
}

\author{
MURAT SATICI
}

Abstract: With an unquestioned look the perception of the law is limited to the legal and legal concepts, practices and concepts such as constitution-law-court-crime-punishment. This situation only raises the institutional, normative and judicial side of law and makes it difficult to ask the philosophical ancient questions that reveal the question of law and the need for the philosophy of law: What is the source of the law and the concepts of justice, right, and freedom? Secondly, what is the source or basis of the legitimacy of the law? Both the question and answer to these two ancient questions are up to the philosophy of law. In this study, the importance of the philosophy of law will be emphasized in the solution of the problems caused by the legalist paradigm which is dominant in the perception of the law. First, we will touch upon the intersection of law with the morality in the natural law tradition. Then, we will emphasize the dilemmas of legal positivism. Finally, we will seek the answer to the question of why we need a philosophy of law besides the science of law.

Keywords: Law, Legality, Justice, Philosophy of law, Philosophy of society. 